\title{
CHARACTERISATION OF OLIVE MILL EFFLUENTS AND TREATMENTS ESSAYS BY SAND FILTERS FOLLOWED BY MACROPHYTES SYSTEMS
}

\author{
Laila MANDI ${ }^{(1,2)}$ \\ Mounia $A C H A K^{(1)}$ \\ Naaila OUAZZANI ${ }^{(1)}$ \\ (1) Laboratory of Hydrobiology, Ecotoxicology and Sanitation, URAC33, \\ Faculty of Sciences Semlalia., Marrakech, Morocco. \\ (2) National Centre of Studies and Research on Water and Energy (CNEREE), \\ University Cadi Ayyad, Marrakech, Morocco.Email : mandi@ucam.ac.ma.
}

\begin{abstract}
Industrial oil olives have a fundamental economic importance for many countries around the Mediterranean Sea. However, during oil olive production, large amount of polluted waters known as olive mill wastewaters (OMW) are generated. Many studies have been undertaken to find efficient treatment systems and several techniques have been tested, but there have been few studies investigating sand filter or macrophytic plants for this type of effluent.

The objective of this work is to study of the suitability of macrophytic plants to treat olive mill wastewater (OMW) after their passage through sand filter.

The experimental pilot consists of a sand filter followed by a planted system. The sand filter is filled with $50 \mathrm{~cm}$ of sand and $10 \mathrm{~cm}$ of gravel in the top and the bottom of the filter. The alimentation $(4 \mathrm{~cm} / \mathrm{j})$ is done sequentially following one day wet /three days dry cycle. In order to activate the degradation processes in the sand filter, OMW are diluted at $50 \%$ by domestic wastewater. The second step of the treatment consists of a tank $\left(1 \times 1 \times 1 \mathrm{~m}^{3}\right)$ filled with $20 \mathrm{~cm}$ of gravel and $60 \mathrm{~cm}$ of soil planted with a mixture of aquatic plants (Phragmites australis, Typha latifolia and Arundo donax) at a density of 25 young plants $/ \mathrm{m}^{2}$ and irrigated two times in the week by 20L of preliminary filtered OMW.

The obtained results show that the sand filter ensures a neutralization of the OMW pH which passes from 4.79 to 7.68 . The enrichment of sand by the micro-organisms makes it possible to have an important mineralization of the organic matter. After ten weeks of operation of this system without clogging sign, the rate of abatement of the TSS, total COD, dissolved COD and phenolic compounds is about $70 \%, 79 \%, 76 \%$ and $81 \%$ respectively. The preliminary outputs by the planted system show a good adaptation of the tested plants to the preliminary treated OMW. The pilot allows an elimination of $94 \%$ of TSS, $99.7 \%$ of total COD, $99.5 \%$ of dissolved COD and $95 \%$ of phenolic compounds.

With regard to OMW treatment efficiency, the results obtained agree with important role of macrophytes for maintaining the aquatic plants treatment capability particularly for wastewater with high organic matter.
\end{abstract}

\section{KEY WORDS}

Olive mill Wastewater, Characterisation, Treatment, Sand filter, Macrophytes, phenolic compounds. 


\section{INTRODUCTION}

Olive Mill Wastewater (OMW) generated by the olive oil extraction industry is a great pollutant because of its high values of biological oxygen demand (BOD 15-135 g/L), chemical oxygen demand (COD 37-318 g/L), high contents of suspended solids (TSS 6-69 $\mathrm{g} / \mathrm{L}$ ) and acidic $\mathrm{pH}$ (4.6-5.8). Direct reuse of this wastewater in agriculture is limited by the phytotoxicity and antimicrobial effects due in particular to its contents in phenolic compounds $(1.5-10 \mathrm{~g} / \mathrm{L})$, low $\mathrm{pH}$ and the presence of toxic fatty acids.

Nevertheless, several methods have been proposed for treating OMW, such as composting [1], evaporation ponds [2], thermal treatment [3], physical-chemical treatment [4], biological treatments [5] and land spreading [6,7,8,9,10].

Macrophytes systems have been used for decades mostly for the treatment of domestic or municipal sewage $[11,12,13,14]$. Recently constructed wetlands have been used for many other types of wastewater including dairy farm wastewaters $[15,16,13,14]$, tool industry wastewater [17], abattoir wastewater [18], tannery wastewater [19], freshwater fish farm wastewater [20] and wood waste leachate [21]. However, at the best of our knowledge, the removal of organic pollutant from OMW by planted system, as an environmentally sensitive and cost-effective treatment system for renovation of wastewater, has not been reported.

The objectives of this work were focused to the study of the suitability of macrophytes to treat olive mill wastewater (OMW) after their passage through sand filter. Main goals were to test a preliminary treatment of OMW by sand filters and to assess the role of macrophytes in the removal of organic pollutant.

\section{MATERIALS AND METHODS}

\subsection{Description of the experimental pilot}

The experimental pilot consists of a sand filter followed by a planted system. The sand filter is filled with $50 \mathrm{~cm}$ of sand and $10 \mathrm{~cm}$ of gravel in the top and the bottom of the filter. The alimentation ( 5 litres) is done sequentially following one day wet /three days dry cycle. In order to activate the degradation processes in the sand filter, OMW were diluted at $50 \%$ by domestic wastewater. The second step of the treatment consists of a tank $\left(1 \times 1 \times 1 \mathrm{~m}^{3}\right)$ filled with $20 \mathrm{~cm}$ of gravel and $60 \mathrm{~cm}$ of soil planted with a mixture of aquatic plants (Phragmites australis, Typha latifolia and Arundo donax) at a density of 25 young plants $/ \mathrm{m}^{2}$ and irrigated two times in the week by 20L of preliminary filtered OMW.

\subsection{Analytical methods}

$\mathrm{pH}$, electrical conductivity (EC), total suspended solid (TSS), Kjeldhal-nitrogen (TKN), ammonia nitrogen $\left(\mathrm{NH}_{4}{ }^{+}\right)$, nitrite $\left(\mathrm{NO}_{2}{ }^{-}\right)$, orthophosphates $\left(\mathrm{PO}_{4}{ }^{3-}\right)$ and total phosphorus (PT) were determined by AFNOR methods [22]. Nitrate $\left(\mathrm{NO}_{3}{ }^{-}\right)$was analysed as nitrites after their reduction through a cadmium-copper column according to the Rodier [23]. Total and dissolved chemical oxygen demand (COD) was determined by a spectrophotometer method APHA [24]. Phenolic compounds were quantified by means of the Folin-Ciocalteau calorimetric method [25] using caffeic acid as standard.

\section{Results and discussion}

\section{1 OMW characterization}

The physical-chemical characteristics of diluted OMW by domestic wastewater summarised in Table 1 and correspond to the mean values of 3 analyses. 
$\mathrm{pH}$

$\mathrm{CE}\left(\mathrm{ms} / \mathrm{cm}\right.$ at $\left.20^{\circ} \mathrm{C}\right)$

Total suspended solids (TSS) (g/L)

Phenolic compounds $(\mathrm{g} / \mathrm{L})$

Total COD $\left(\mathrm{g} \mathrm{O}_{2} / \mathrm{l}\right)$

Dissolved COD $\left(\mathrm{g} \mathrm{O}_{2} / \mathrm{l}\right)$

TKN-N (g/L)

$\mathrm{NH}_{4}{ }^{+}-\mathrm{N}(\mathrm{mg} / \mathrm{L})$

$\mathrm{NO}_{2}^{-}-\mathrm{N}(\mathrm{mg} / \mathrm{L})$

$\mathrm{NO}_{3}{ }^{-} \mathrm{N}(\mathrm{mg} / \mathrm{L})$

$\mathrm{P}-\mathrm{PO}_{4}{ }^{3-}(\mathrm{g} / \mathrm{L})$

Total phosphorus $(\mathrm{g} / \mathrm{L})$

\section{4,79}

5,87

$1,39 \pm 0,01$

$5,69 \pm 0,15$

$26,78 \pm 0,52$

$20,47 \pm 1,56$

$2,05 \pm 0,05$

$1,52 \pm 9,3$

$1,94 \pm 0,01$

$1,70 \pm 0,05$

$0,22 \pm 0,01$

$0,30 \pm 0,04$

Physical-chemical analysis showed that the diluted OMW was an acidic effluent ( $\mathrm{pH} 4.79$ ). The electrical conductivity was very low $(5.87 \mathrm{mS} / \mathrm{cm})$ compared to that usually reported for urban effluent in Marrakech and which, according to Zenjari et al., (1999) [26] varies between 25.3 and $36.6 \mathrm{mS} / \mathrm{cm}$. OMW contains high concentration of total suspended solids (TSS 1.39 $\mathrm{g} / \mathrm{L})$, in addition to having a much higher total COD value $(26.78 \mathrm{~g} / \mathrm{L})$, hence a higher concentration of organic components. Toxicity in this type of effluent can arise from the high levels of phenolic compounds $(5.69 \mathrm{~g} / \mathrm{L})$. The toxicity of OMW is mainly due to its phenolic or polyphenolic compounds. OMW has a high content of the mineral fraction; in particular of TKN $(2.05 \mathrm{~g} / \mathrm{L})$, total P $(0.30 \mathrm{~g} / \mathrm{L})$.

\subsection{Water quality and performance efficiency of sand filter}

Results of the physical-chemical analyses of input and output after infiltration through sand filter are presented in table 2. It can be observed that OMW underwent important changes in composition after passing through the sand. 
Table 2. Removal efficiency of sand after the infiltration of OMW (data are means of three replicates).

\begin{tabular}{lll}
\hline Parameters & OMW pre-treated & $\%$ Removal \\
\hline $\mathrm{pH}$ & 7,68 & - \\
Conductivity $\mathrm{mS} / \mathrm{cm}$ & 7,36 & - \\
TSS g/L & $0,36 \pm 0,05$ & 70 \\
Total phenols g/L & $0,60 \pm 0,15$ & 81 \\
Total COD g/L & $5,25 \pm 0,30$ & 79 \\
Disolved COD g/L & $4,88 \pm 1,22$ & 76
\end{tabular}

The treatment of OMW by sand filter maintained $\mathrm{pH}$ close to neutrality, it's increased from 4.79 to 7.68 ; this could be due to the fixation of organic acids, responsible for a low $\mathrm{pH}$ value, on sand particles. The evolution of electrical conductivity (EC) in the sand filter showed that the infiltration of the OMW through sand filter involved an increase from 5.87 to $7.36 \mathrm{mS} / \mathrm{cm}$. Table 2 showed a very significant reduction of TSS (70\%), this could be due to the physical processes (sedimentation and filtration). The total COD, dissolved COD and phenolic compounds content significantly decrease after passing through the sand. Indeed, the total COD decreased from $26.78 \pm 0.52 \mathrm{~g} / \mathrm{L}$ to $5.25 \pm 0.30 \mathrm{~g} / \mathrm{L}$ with a reduction of $79 \%$, the dissolved COD decreased from $20.47 \pm 1.56 \mathrm{~g} / \mathrm{L}$ to $4.88 \pm 1.22 \mathrm{~g} / \mathrm{L}$ with a reduction of $76 \%$ and phenolic compounds decreased from $5,69 \pm 0,15 \mathrm{~g} / \mathrm{L}$ to $0.60 \pm 0.15 \mathrm{~g} / \mathrm{L}$ with a reduction of $81 \%$.

\subsection{Water quality and performance efficiency of experimental system}

Analysis of $\mathrm{pH}, \mathrm{EC}$, total COD, dissolved COD and phenolic compounds were determined periodically at the inlet of sand filter and outlet of macrophytes tank.

Fig. 1 shows that the $\mathrm{pH}$ of the raw OMW at the inlet of the experimental system (sand filter followed by a macrophytes tank) varied between 4.2 and 5.7 with an average value of 4.7. The $\mathrm{pH}$ of the treated OMW at the outlet of the experimental system increased from two to three units, with an average value of 8.09 . This could be explained by the buffer capacity of the soil $(\mathrm{pH}=8.45)$ and its aptitude to be resist $\mathrm{pH}$ variations. 


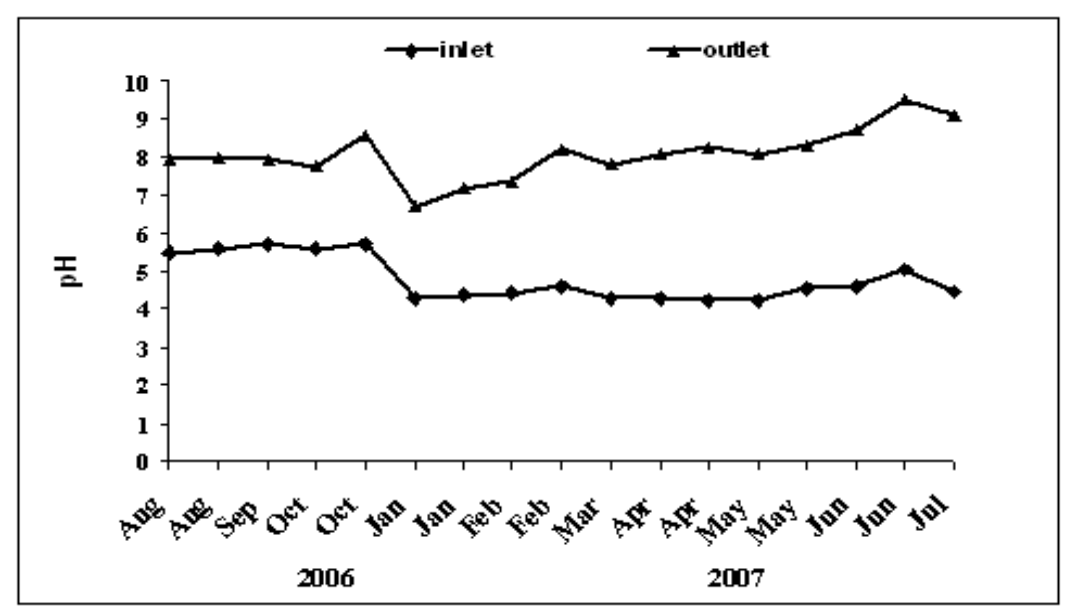

Figure 1. Temporal changes in $\mathrm{pH}$ of the olive mill wastewater at input and output of the experimental system.

The electrical conductivity of the OMW from the outlet of the experimental system is constantly higher than that of the inlet (Fig. 2). This increase is accentuated during (May at July). During the period August-September the difference in conductivity between the inlet and outlet of the experimental system is found to be very slight demonstrating a significant acclimatation and development of the plants. The average electrical conductivity of the raw and treated OMW is about 5.8 and $8.8 \mathrm{mS} / \mathrm{cm}$ respectively.

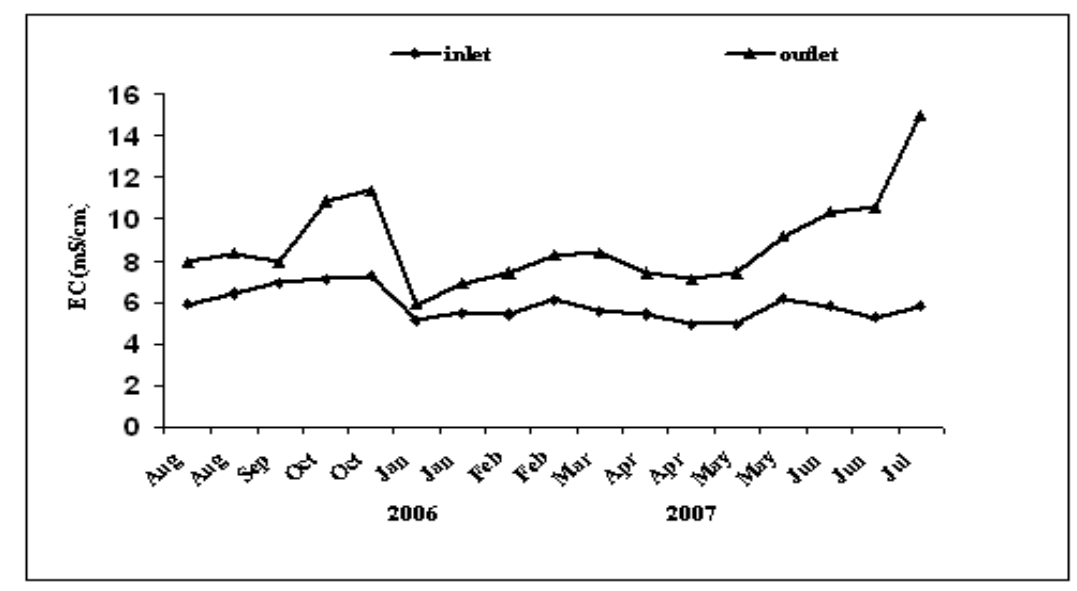

Figure 2. Temporal changes in conductivity of the olive mill wastewater at the input and output of the experimental system.

Evolution of TSS content at the inlet and outlet of the experimental system are reported in Figure 3. TSS concentrations at the inlet varied from $0.55 \mathrm{~g} / \mathrm{L}$ to $2 \mathrm{~g} / \mathrm{L}$ with an average content of $1.39 \mathrm{~g} / \mathrm{L}$. At the outlet, TSS concentrations are very weak and oscillate around an average value of $0.37 \pm 0.04 \mathrm{~g} / \mathrm{L}$. 


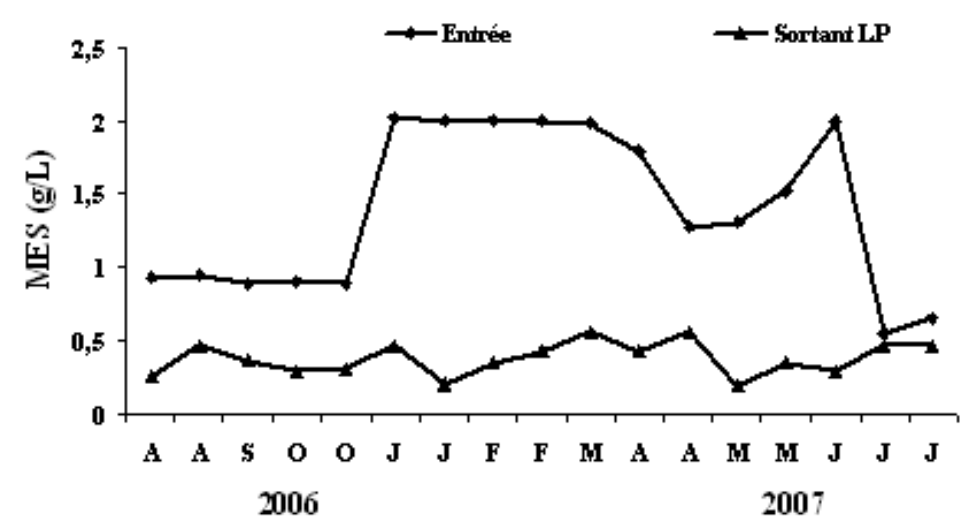

Figure 3. Temporal changes in TSS of the olive mill wastewater at the input and output of the experimental system.

The TSS elimination varied from $82 \%$ to $99 \%$ with an average elimination of $94 \%$ (table 2 ). This reduction may be explained mainly by physical processes (sedimentation and filtration).*

Table 3.Evolution of removal yield of TSS, total COD, dissolved COD and phenolic compounds of system (August 2006-July 2007).

\begin{tabular}{lccccccccccc}
\hline $\begin{array}{l}\text { Paramètres } \\
\%\end{array}$ & Aug & Sept & Oct & Jan & Feb & Mar & Apr & May & Jun & Jul \\
\hline TSS & 82,0 & 82,0 & 90,0 & 97,0 & 97,0 & 99,0 & 94,0 & 98,0 & 98,0 & 99,0 \\
& & & & & & & & & & \\
Total COD & 99,3 & 99,4 & 99,6 & 99,7 & 99,8 & 99,9 & 99,6 & 99,9 & 99,8 & 99,9 \\
$\begin{array}{l}\text { Dissolved } \\
\text { COD }\end{array}$ & 99,0 & 99,0 & 99,4 & 99,7 & 99,7 & 99,9 & 99,6 & 99,8 & 99,8 & 99,9 \\
$\begin{array}{l}\text { Phenolic } \\
\text { compound }\end{array}$ & 86,0 & 86,9 & 92,03 & 99,3 & 99,3 & 99,7 & 89,8 & 99,6 & 99,5 & 99,8 \\
\hline
\end{tabular}

Evolution of total COD content at the inlet and outlet of the experimental system are reported in Figure 4. Total COD concentrations at the inlet varied from $17 \mathrm{~g} / \mathrm{L}$ to $31 \mathrm{~g} / \mathrm{L}$ with an average content of $27 \mathrm{~g} / \mathrm{L}$. At the outlet, total COD concentrations varied from $1.06 \mathrm{~g} / \mathrm{L}$ to 9 $\mathrm{g} / \mathrm{L}$ with an average value of $8 \mathrm{~g} / \mathrm{L}$. 


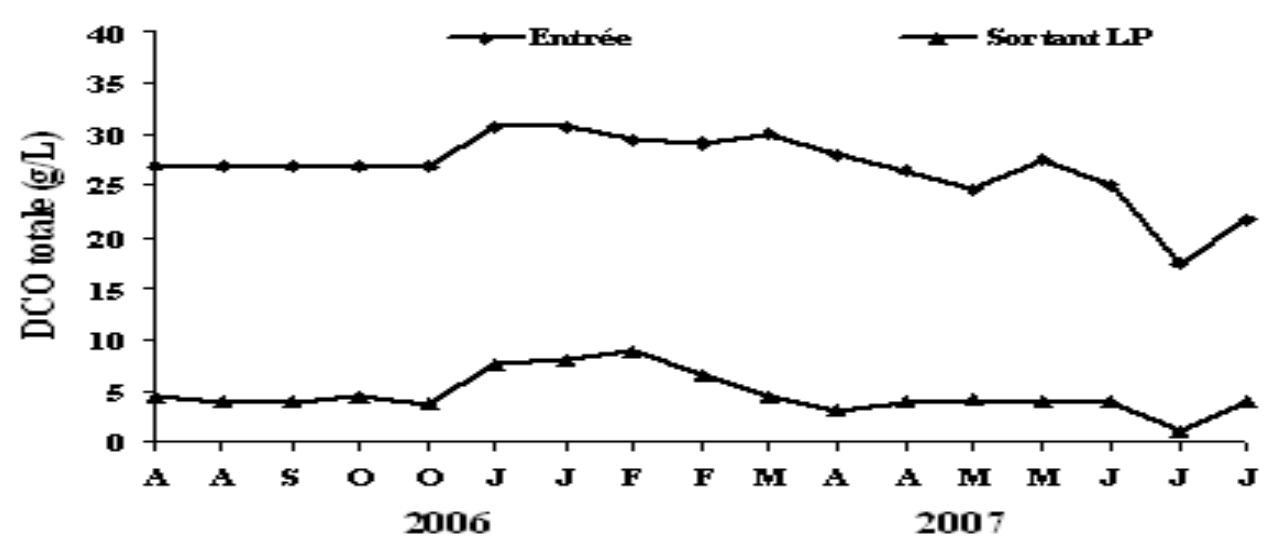

Figure 4. Temporal changes in total COD of the olive mill wastewater at the input and output of the experimental system.

Evolution of disolved COD content at the inlet and outlet of the experimental system are reported in Figure 5. Dissolved COD concentrations at the inlet varied from $17 \mathrm{~g} / \mathrm{L}$ to 27.34 $\mathrm{g} / \mathrm{L}$ with an average content of $20.47 \mathrm{~g} / \mathrm{L}$. At the outlet, dissolved COD concentrations varied from $2.38 \mathrm{~g} / \mathrm{L}$ to $9 \mathrm{~g} / \mathrm{L}$ with an average value of $4.55 \mathrm{~g} / \mathrm{L}$.

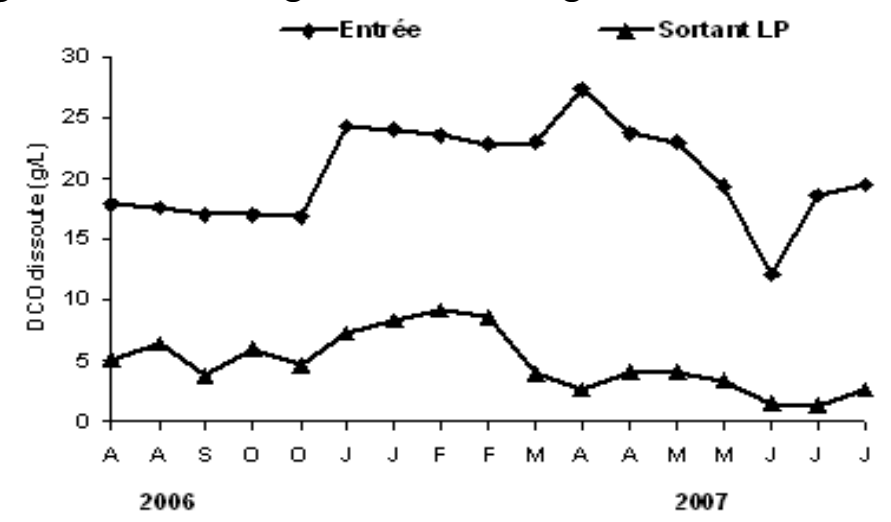

Figure 5. Temporal changes in dissolved DOC of the olive mill wastewater at the input and output of the experimental system.

As can be seen in Table 3, the average removal of total COD and dissolved COD was high $99.5 \%$ and 99.7 respectively. This elimination can be explained by the better oxygenation of the soil allowing aerobic bacteria to proliferate and consequently provide a better mineralization or oxidation of organic matter.

The phenolic compounds concentrations at the inlet varied from $1.19 \mathrm{~g} / \mathrm{L}$ to $8.5 \mathrm{~g} / \mathrm{L}$. At the outlet, phenolic compounds concentrations oscillate around an average value $0.4 \mathrm{~g} / \mathrm{L}$. 


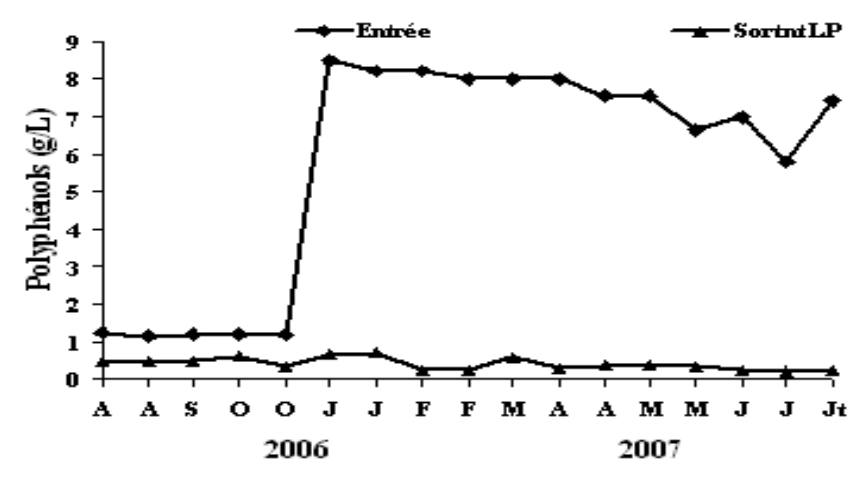

Figure 5. Temporal changes in phenolic compounds of the olive mill wastewater at the input and output of the experimental system.

The elimination of phenolic compounds is very important; it is the order of $95 \%$ (Table 3 ). This elimination can be explained by the aerobic and anaerobic bacteria degradation, absorption by plants, volatilization, and the storage in the soil.

\section{CONCLUSION}

This study was conducted to test the elimination of organic matter of diluted olive mill wastewater by sand filers followed by macrophytes. The physical-chemical analysis of diluted OMW shows that it is a highly acidic effluent ( $\mathrm{pH} 4.79$ ), very loaded in terms of total COD (26.78 g / L), dissolved COD (20.47 g / L) and phenolic compounds (5.69 g / L).

The pretreatment of OMW by the sand filter provided an increase in $\mathrm{pH}$ by three units after the buffering capacity of the sand and its power to oppose the change in $\mathrm{pH}$. A significant removal of TSS and organic load (TSS: 70\% total COD: $79 \%$ dissolved COD: $76 \%$ and phenolic compounds: $81 \%$ ). The COD removal indicates that a good bacterial assimilation takes place in the sand filter. The reduction of phenolic compounds is explained by the polymerization and / or bioconversion of tyrosol and hydroxytyrosol.

Treatment with the combination of a sand filter followed by macrophytes ensured a significant removal of organic load. The removal of TSS by the system is about $94 \%$, the reduction of phenolic compounds is always greater than $80 \%$ at the start experience. In the case of COD removal, the combination of two systems showed a major importance in the degradation of organic matter. Indeed, the reduction of COD and total dissolved is about $99.7 \%$ and $99.5 \%$ respectively.

With regard to OMW treatment efficacy, the results obtained agree with important role of macrophytes for maintaining the aquatic plants treatment capability particularly for wastewater with high organic matter.

\section{REFERENCES}

[1] Chatjipavlidis, I., Antonakou, M., Demou, D., Flouri, F., Balis, C., 1996. Biofertilization of olive mills liquid wastes. The pilot plant in Messinia, Greece. Int Biodeterior Biodegrad, 183-7.

[2] Mountadar, M., Kissi, M., Assobhei, O., Lekhlif, B., Laplange, J., 1997. Caractérisation physico-chimique et traitement d'un effluent d'huilerie d'olive (margines). Colloque international. « Gestion des rejets industriels pour un développement durable ». El Jadida. 
[3] Baccioni, L., 1981. Riciclo elle acque e lero incenerimento : Una solazione per la depurazione delle acque dei frantoi. Riv. Ital. Sostanze Grass. L. V. III. 34-37.

[4] Achak, M., Ouazzani, N., Yaacoubi, A Mandi, L., 2008. Caractérisation des margines issues d'une huilerie moderne et essai de leur traitement par coagulation-floculation par la chaux et le sulfate d'aluminium. Science de l'eau 21, 53-57.

[5] Mantzavinos, D., Kalogerakis, N., 2005. Treatment of olive mill effluents. Part. I. organic matter degradation by chemical and biological processes-an overview, Environment International 31, 289-295.

[6] Sierra, J., Marti, E., Montserrat, G., Crunas, R., M Garau, A., 2001. Characterisation and evolution of a soil affected by olive oil mill wastewater disposal, the Science of the Total Environment 279, 207-214.

[7] Mechri, B., Attiab, F., Brahamb, M., Ben Elhadjc, S., Hammamia, M., 2007. Agronomic application of olive mill wastewaters with phosphate rock in a semi-arid Mediterranean soil modifies the soil properties and decreases the extractable soil phosphorus. Journal of Environmental Management 85, 1088-1093.

[8] Mechri, B., Attiab, F., Brahamb, M., Ben Elhadjc, S., Hammamia, M., 2008. Change in soil properties and the soil microbial community following land spreading of olive mill wastewater affects olive trees key physiological parameters and the abundance of arbuscular mycorrhizal fungi. Soil Biology and Biochemistry 40, 152-161

[9] Mekki, A., Dhouib, A., Sayadi, S., 2007. Polyphénols dynamics and phytotoxicity in a soil amended by olive mill wastewaters, Journal of Environment Management 84, 134-140.

[10] Saadi, I., Laor, Y., Raviv, M., Medinas, S., 2007. Land spreading of olive mill wastewater: Effect on soil microbial activity and potential phytotoxicity, Chemosphere 66, $75-83$.

[11] Mandi, L., Bouhoum, K., Ouazzani, N., 1998. Application of constructed wetlands for domestic wastewater treatment in an arid alimate. Wat. Sci. Tech., 38, 429-434.

[12] Abissy, M., Mandi, L., 1999. Comparative study of wastewater purification efficiencies of two emergent helophytes: Typha latifolia and Juncus subulatus under arid climate. Wat. Sci. Tech., 39, 123-126.

[13] Ansola, G., Gonzalez, J.M., Cortijo, R., De Luis, E., 2003. Experimental and full-scale pilot plant constructed wetlands for municipal wastewaters treatment. Ecol. Eng., 21, 43-52.

[14] Ciria, M.P., Solano, M.L Soriano, P., 2005. Role of macrophyte Typha latifolia in a constructed wetland for wastewater treatment and assessment of its potential as a biomass fuel. Biosystems Engineering, 92, 535-544.

[15] Tanner, C.C., Clayton, J.S., Upsdell, M.P., 1995. Effect of loading rate and planting on treatment of dairy farm wastewaters in constructed wetlands-II. Removal of nitrogen and phosphorus. War. Res., 29, 27-34.

[16] Boutin, C., Liénrd, A., Esser, D., 1996. Development of a new generation of reed-bed filters in France: First-results. Proceeding of 5th International conference on wetlands systems for water pollution control, vol. 2, 15-19 sept, Vienna, pp. 8.

[17] Hadad, H.R., Maine, M.A., Bonetto, C.A., 2006. Macrophyte growth in a experimental system-scale constructed wetland for industrial wastewater treatment. Chemosphere, 63, 1744-1753.

[18] Rivera, F., Warren, A., Curds, C.R., Robles, E., Gutierrez, A., Gallegos, E., Calderon, A., 1997. The application of the root zone method for the treatment and reuse of high strength abattoir waste in Mexico. Wat. Sci. Tech., 35, 271-278.

[19] Tiglyéne, S., Mandi, L., Jaouad, A., 2005. Enlèvement du chrome par infiltration verticale sur lits de Phragmites australis (Cav.) Steudel. Science de l'eau, 18, 177-198. 
[20] Naylor, S., Brisson, I., Labelle, M.A., Drizo, A., Comeau, Y., 2003. Treatment of freshwater fish farm effluent using constructed wetlands: the role of plants and substrate. Wat. Sc.Tech., 485, 215-222.

[21] Masbough, A., Frankowski, K., Hall, K.J., Sheldon J.B.D., 2005. The effectiveness of constructed wetland for treatment of woodwaste leachate. Ecological Engineering, 25, 552566.

[22] AFNOR, 1983. Recueil de norme française : eau, méthodes d'essai, 2éme édition, Paris, pp. 621.

[23] Rodier, J., 1984. L'analyse de l'eau: eaux naturelles, eaux résiduaires, eau de mer, 7éme édition : DUNOD, BORDAS, Paris, pp. 1365.

[24] APHA, 1992. American Public Health Association 1992. Standard Methods for Analysis of Waste and Waste Water.Washington Dc.

[25] Box, JD., 1983. Investigation of the Folin Ciocalteu phenol reagent for the determination of polyphenolic substances in natural waters. Water res., 17, 511-525.

[26] Zenjari, B., Hafidi, M., El Hadrami, I., Bailly, J.R., Nejmeddine, A., 1999. Traitement aérobie des effluents d'huileries par les microorganismes du sol. Agrochimica, XLIII 276-85. 